\title{
Reflexões sobre paisagens e fotografias da Odisseia 116
}

\section{Cleilson Queiroz Lopes}

\author{
Universidade Federal do Estado \\ do Rio de Janeiro \\ Rio de Janeiro, RJ, Brasil \\ cleilson-lopes@hotmail.com \\ orcid.org/0000-0002-6469-211X
}

Resumo I Este artigo discute as questões teóricas e práticas que fotografias e paisagens suscitam para a dramaturgia Odisseia 116. Como metodologia, inspiro-me em aspectos da genética teatral. Levo em consideração $o$ fato de fotografias serem documentos imprescindíveis para a realização do projeto em suas potencialidades de arquivo material do processo.

PALAVRAS-CHAVE:

Fotografia. Paisagem. Dramaturgia.

\author{
Reflections on landscapes and \\ photographs from Odisseia 116
}

Abstract | This article discusses the theoretical and practical issues that photographs and landscapes raise for the dramaturgy Odisseia 116. As a methodology, I am inspired by aspects of theatrical genetics. I take into consideration, the fact that photographs are essential documents for the realization of the project in its potentialities of material file of the process.

KEYWORDS: Photography.

Landscape. Dramaturgy.

Reflexiones sobre paisajes y fotografías de la Odisseia 116

Resumen | Este artículo analiza las cuestiones teóricas y prácticas que las fotografías y los paisajes plantean para la dramaturgia Odisseia 116. Como metodología, me baso en aspectos de la genética teatral. Tomo en cuenta que las fotografías son documentos imprescindibles para la realización del proyecto en su potencialidad como archivo material del proceso.

PALABRAS CLAVE: Fotografía. Paisaje. Dramaturgia.

Enviado em: $15 / 05 / 2021$

Aceito em: 28/10/2021

Publicado em: 17/11/2021 


\section{Introdução}

Nasci no ano de 1990 em uma cidade de pouco mais de cem mil habitantes localizada no interior do estado do Ceará que se chama Iguatu. Morei em um Conjunto Habitacional - $\mathrm{COHAB}$, sempre frequentando a escola pública e projetos sociais. Meu pai se chama Antônio, tem 79 anos e é aposentado como mecânico. Minha mãe se chama Francisca, tem 66 anos e é dona de casa. Ambos estudaram apenas até a quinta série, tendo em vista a necessidade de parar os estudos para trabalhar na roça ainda quando crianças.

Consegui com muito esforço romper o ciclo da falta de oportunidades por meio de políticas públicas e da democratização universitária que inicia-se em 2003, sendo assim, fui o primeiro da minha família a alcançar o ambiente universitário.

Quando fui aprovado para o curso de Licenciatura em teatro na Universidade Federal do Estado do Rio de Janeiro - UNIRIO e me mudei para o Rio de Janeiro no ano de 2014, não imaginava que a distância da minha terra, amigos, familiares e paisagens que conhecia seria um grande fardo para mim, como em alguns momentos foi.

Esta viagem, feita de ônibus em três dias pela BR-116, envolvia não um deslocamento qualquer, mas um rumo para quem estava à deriva. A mudança, que apontava para a cidade do Rio de Janeiro, não se limitava mais à grande cidade, pois esta já não era mais para mim a cidade de cartão postal, a cidade maravilhosa somente, mas seria uma cidade vivenciada no dia-a-dia.

Comecei a refletir sobre o lugar da emigração no Rio de Janeiro e no ano de 2016 decidi que meu projeto de mestrado para a UNIRIO seria uma pesquisa teórico-prática sobre o desejo de retorno para casa. Naquele momento, a Odisseia homérica me parecia uma obra estreitamente relacionada ao meu desejo de voltar, tendo em vista ser um dos pilares da literatura ocidental e uma narrativa sobre o retorno.

Decidi, portanto, realizar a viagem de retorno de ônibus para minha casa no interior do Ceará no ano de 2016 e neste percurso entrevistar pessoas e fotografar a experiência para em seguida elaborar uma dramaturgia. Durante o processo de escrita, a dramaturgia recebeu o nome Odisseia 116.

A dramaturgia Odisseia 116 alicerça-se sobre uma tríade: questões autobiográficas de retorno; a Odisseia homérica como fonte de inspiração; e as fotografias, paisagens e entrevistas dos emigrantes realizadas em viagem como disparadoras de cenas possíveis.

A dramaturgia Odisseia 116 foi finalizada durante meu processo de mestrado no ano de 2017 e é um manuscrito inédito que está em processo de edição para publicação em livro. No ano de 2022 começaremos estudos para uma possível encenação pela Companhia Ortaet de teatro, da qual faço parte na cidade de Iguatu-Ce. Neste artigo irei me deter na construção dramatúrgica.

Imagens, paisagens, pessoas, fronteiras, cartografias estão em constante transformação. Todavia, enquanto projeto teórico-prático, que visa a elaboração de uma dramaturgia em dois atos a partir de uma série de entrevistas e fotografias, confesso que as palavras voltar e retorno me vinham de forma romântica e docilizada.

No entanto, a cada paisagem e entrevista essas palavras se reinventavam 
em mim, me tirando do conforto de um roteiro estabelecido de perguntas e me impulsionando a sair da minha inércia, me coagindo a afetar e ser afetado pelos mais diferentes discursos e pessoas. Debato aqui algumas fotografias que integram o projeto Odisseia 116 e a forma como estas interferem e constroem a dramaturgia.

Como metodologia, me aproximo neste artigo da genética teatral por compreender que a mesma auxilia-me na aproximação dos aspectos documentais da escrita desta dramaturgia. No artigo Por uma genética teatral: premissas e desafios, Grésillon, Mervant-Roux e Budor (2013), afirmam que o debate da crítica genética no teatro causa uma reviravolta, pois se o poema ou mesmo o romance apresentavam-se, por vezes, fechados ou acabados, o teatro pelo contrário demonstrava ser um campo fértil, tendo em vista que com a encenação teatral que surge no início do século XX, o teatro apresenta-se cada vez mais como um campo aberto ao estudo e assimilação de vários materiais de diferentes formas, tipos e origens, podendo assim ser modificado, ampliado ou reduzido (GRÉSILLON; MERVANT-ROUX; BUDOR, 2013).

Em relação à utilização das fotografias no projeto de escrita Odisseia 116, há um movimento reflexivo sobre o interesse, o desejo, o que puxa o olhar na viagem e dispara lembranças na escrita da dramaturgia. Segundo Maíra Barillo, em seu artigo intitulado Fotografia ficção: sobre a fotografia de performances e performatividades (2019), refletir sobre fotografias tiradas tem uma força política necessária de ser discutida. É possivel, ao refletir sobre as próprias fotografias, conscientizar-se das dinâmicas de poder que influenciam o processo de fotografar. (BARILLO, 2019). No presente artigo, dentro de mais de quinhentas fotografias feitas em viagem, opto por três que me causam sensações, reflexões e problemáticas diretamente relacionados com a escrita da dramaturgia Odisseia 116.

\section{Fotografia e paisagem}

É necessário esclarecer antes de tudo que não sou fotógrafo profissional. Meu primeiro contato com a câmera se deu com o projeto de escrita da dramaturgia Odisseia 116. Foi na viagem que descobri coisas como tempo de disparo, obturador e manuseio do sistema da câmera. Por essa razão tive que resolver problemas técnicos rapidamente em percurso, diferentemente do processo dramatúrgico. Apesar de já ter certa experiência com a escrita, resolvi que a dramaturgia não seria feita em percurso, mas logo após a viagem e inspirado pelas fotografias, paisagens e entrevistas.

As dificuldades com a câmera foram resolvidas relativamente rápido, ao contrário da dramaturgia escrita, marcada por meses de crise. Todavia a relação da fotografia com a palavra neste projeto é muito próxima. Algumas fotografias funcionaram como o disparador para a escrita de cenas inteiras. As paisagens e sua rápida mudança abriam dentro de mim um mundo de possibilidades na inocência de alguém que viaja descobrindo uma câmera fotográfica. ${ }^{1}$

${ }^{1}$ A câmera foi comprada com o cachê de um projeto anterior a este e chegou dois dias antes de a 
Ao mesmo tempo que a câmera puxava meu olho para um recorte específico da paisagem em dinâmica no ônibus, ela também o projetava para fora. Era através das fotografias que eu me percebia e percebia os emigrantes neste percurso.

A possibilidade de rever a imagem não pela janela, mas por um recorte específico da fotografia, me faz pensar na capacidade de sua infinita reprodutibilidade, ou mesmo de sua edição. Neste sentido, tenho nas mãos dois tipos de materiais: a memória da paisagem em si e o recorte feito pela câmera naquele instante, suscetível a inúmeros tipos de reprodução e utilização tanto para a cena quanto para a dramaturgia. As imagens aqui utilizadas não passaram por um processo de edição.

Compreendo o termo paisagem neste trabalho, não como lugar delimitado ou mesmo como natureza estática, mas como uma elaboração que também é simbólica, sensível e dinâmica, construída culturalmente, conforme aponta Javier Maderuelo (2005):

A paisagem não é [...] o que está aí, diante de nós, mas um conceito inventado ou, melhor, uma construção cultural. A paisagem não é um mero lugar físico, e sim o conjunto de uma série de ideias, sensações e sentimentos que elaboramos a partir do lugar e seus elementos constituintes. A palavra paisagem [...] reclama também algo mais: reclama uma interpretação, a busca de um caráter e a presença de uma sensibilidade. [...] A ideia de paisagem não se encontra tanto no objeto que se contempla como na mirada de quem contempla. Não é o que está a sua frente e sim o que se vê. (MADERUELO, 2005 apud GUIMARÃES, 2016, p. 40).

A paisagem na dramaturgia Odisseia 116 é também um caminho que percorro para elaborar um discurso cênico a partir das minhas sensações e vivências em viagem. São paisagens percebidas em dinâmica não somente pela velocidade do ônibus, mas pela minha presença e meu corpo que também é singular e único no percurso. Minha tentativa é então ensaiar narrativas possíveis entre estes dois espaços: o das fotografias expostas e o das paisagens, na tentativa de perceber os caminhos possíveis que ambas apontam.

Tanto a fotografia quanto a paisagem são dispositivos usados na estrutura da dramaturgia Odisseia 116, pois a viagem é citada, seus pontos são por vezes localizados e as pessoas entrevistadas estão em espaços escolhidos e concretos do percurso feito entre o Rio de Janeiro e o Ceará. Logo, as paisagens interferem na dinâmica das ações e sensações das pessoas.

Os entrevistados transpareciam nas suas falas questões de saudade, esperança, abandono, desilusão, rompimento, expectativa e ansiedade, e estas questões aparecem na dramaturgia. Por último, meu próprio corpo em viagem, sofrendo ações do percurso é também uma questão para o texto e para a cena.

As imagens aqui analisadas serviram como disparadoras da dramaturgia. Foram tiradas mais de quinhentas fotografias em seis dias de viagem e as fotografias comentadas produziram, pela sua forma ou dinâmica, questões que aparecem na dramaturgia e que poderão ou não integrar uma futura encenação. Nenhuma fotografia aqui comentada estará obrigatoriamente presente na 
encenação, mas funciona como esboço e, assim como a palavra, está sujeita à mudança e redirecionamento. O seu estatuto de fantasma dentro da dramaturgia é irremediável, levando em conta que estará sempre retroalimentando-a, sem estar necessariamente presente em cena.

Walter Benjamin (2012), em seu ensaio Pequena história da fotografia, diferencia a prática do pintor da do fotógrafo, afirmando que enquanto no quadro pintado o interesse desaparecia duas ou três gerações depois, ficando apenas o interesse no talento do pintor; a fotografia não se limitaria ao talento do fotógrafo, mas reclamaria algo que não pode ser silenciado, algo que realmente esteve ali e que não se extingue no campo da arte. (BENJAMIN, 2012) A fotografia na construção da dramaturgia Odisseia 116 também prevê o caráter de testemunho e posterioridade, uma relação direta com o real do instante fotografado, mas utilizado na cena.

Há então uma tentativa de apropriação e captura do instante que é defendida por Susan Sontag (2004), em seu livro Sobre Fotografia. Para Sontag:

As fotos são, de fato, experiência capturada, e a câmera é o braço ideal da consciência, em sua disposição aquisitiva. Fotografar é apropriar-se da coisa fotografada. Significa pôr a si mesmo em determinada relação com o mundo (SONTAG, 2004, p. 7).

Na viagem para a escrita da Odisseia 116 a fotografia funcionoua como esta tentativa de capturar um instante, uma experiência, ainda que a fotografia não seja uma experiência em si, mas uma interpretação da mesma, um traço com recorte e foco específicos. Dito de outra forma, as fotografias não são a experiência da viagem, mas a seleção, o recorte e o direcionamento que faço enquanto fotógrafo, tentando capturar algo incapturável para em seguida projetar enquanto texto.

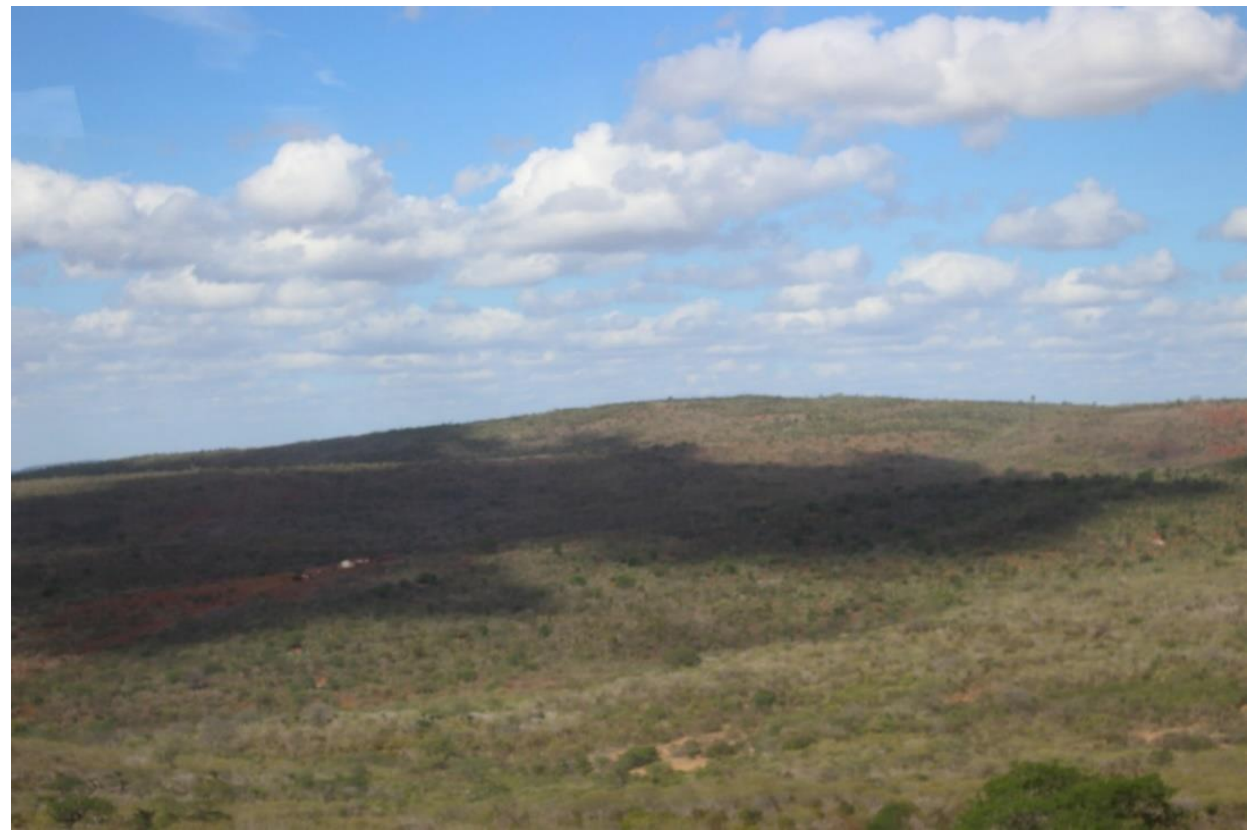

Figura 1. Fotografia do autor. Arquivo pessoal, 2017. 
A Figura 1 inspirou a quarta cena da dramaturgia Odisseia 116, Ilha de Eolo. Eolo é a ilha do deus dos ventos citada na Odisseia homérica, uma ilha impossível de ser mapeada por estar em constante movimentação. Imagens como esta, em que as nuvens sombreavam a vegetação, me remetiam a esta ilha presente na Odisseia homérica. Eolo é o deus que por vezes direciona Odisseu e por vezes faz com que ele se perca com seu sopro. Esta fotografia é isto: o clique de um instante que se perde rapidamente dentro de um percurso preciso, que é o da viagem. Neste sentido, ela é uma paisagem à deriva dentro do movimento que é viajar pela BR-116.

Não somente eu estava em movimento dentro do ônibus, mas a própria imagem se movimentava. Devido ao sopro de Eolo, as nuvens eram muito dinâmicas e produziam diferentes sombras sobre as regiões que iam cobrindo ou desvendando. A repetição exata de uma fotografia se tornava impossível não somente pelo fato de o ônibus estar em movimento, mas também porque a própria paisagem se movimentava, com nuvens que nunca cobrem ou desvendam a vegetação da mesma forma. Então as paisagens não mudavam apenas em razão do movimento do ônibus ou da mudança de cidade e vegetação, mas a própria ação do tempo transformavaa delicadamente. O acaso acaba sendo grande companheiro da fotografia, como salienta Walter Benjamin.

Apesar de toda a perícia do fotógrafo e de tudo o que existe de planejado em seu comportamento, o observador sente a necessidade irresistível de procurar na imagem a pequena centelha do acaso, do aqui e agora, com a qual a realidade chamuscou a imagem (BENJAMIN, 2012, p. 94).

Para Benjamin, o olho não capta aquilo que a câmera percebe no instante congelado (BENJAMIN, 2012). Estas paisagens vistas apenas através da câmera, me fizeram perceber suas dinâmicas e como o acaso opera na relação direta com as fotografias.

Outros instantes, porém, foram fisgados pelo olhar, mas perdidos pela câmera. A possibilidade de rever a imagem foi de extrema relevância para o processo, pois me permitiu analisar concretamente as questões das paisagens e utilizá-las como disparadoras na elaboração dramatúrgica. Era como olhar para uma cicatriz e rememorar um trauma vivido. ${ }^{2}$

2 O debate sobre trauma e cicatriz na escrita da dramaturgia Odisseia 116, e como tais conceitos reverberaram em cenas possíveis, foram discutidos no artigo de minha autoria intitulado O Trauma e a cicatriz na escrita da Odisseia 116 (2021), disponível no link: 


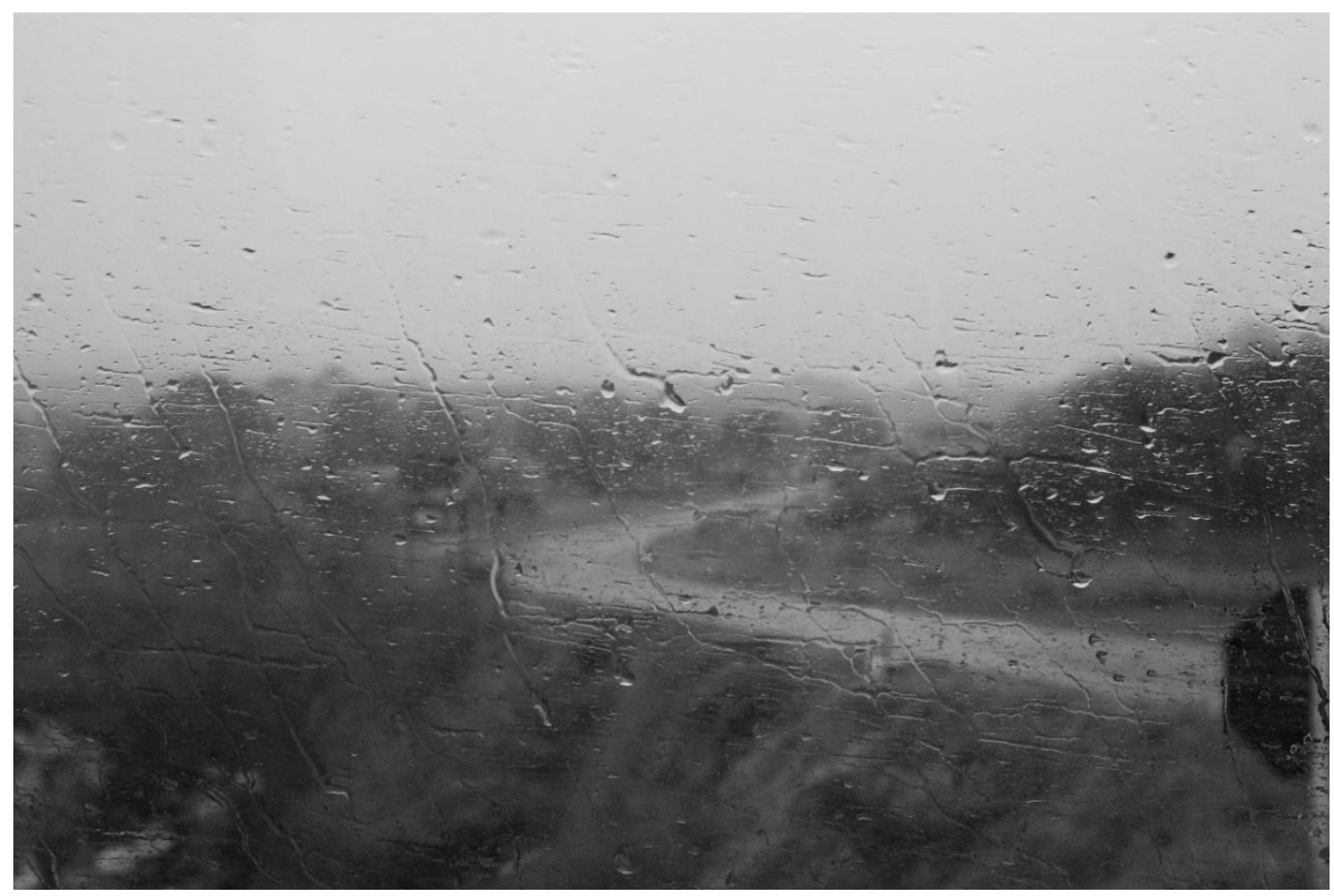

Figura 2. Fotografia do autor. Arquivo pessoal, 2017.

A Figura 2 é uma das primeiras fotos em preto e branco. A imagem me interessa por alguns motivos específicos. O mais importante deles é desvendar o vidro da janela do ônibus através da chuva, situando assim o meu lugar atrás de duas películas de vidro, sendo a primeira a lente da câmera e a segunda a janela. É uma fotografia que não somente recorta uma paisagem fora da janela, mas que me situa como fotógrafo atrás do vidro.

O vidro da janela é um objeto importante para a dramaturgia: o toque na janela e a sensação de por vezes ultrapassá-la manifestam-se de forma salientada na cena quatro, Ilha de Eolo:

\begin{abstract}
Existe uma janela. Um vidro entre mim e o horizonte. Todas as imagens, todas as paisagens são dinâmicas, são móveis. São imagens em devir. Elas vão se transformando com muita velocidade. Há um movimento duplo acontecendo dentro de mim. O primeiro deles me chama a observar as pessoas dentro do ônibus e o segundo me puxa para fora com uma força descomunal, para um horizonte muitas vezes úmido, frio, nebuloso, outras árido, seco, castigado, engraçado, colorido, obscuro, nostálgico. É então que sem perceber, minha mão tocava a janela do ônibus. Como se através do tato do vidro transparente, eu conseguisse sentir a imagem. Sabe, senti-la se formando, se embaçando, se deformando, deixa-la ficar para trás ou muitas vezes seguí-la até o último suspiro. (LOPES, 2017, p. 4).
\end{abstract}

A janela denuncia minha localização no percurso em boa parte das fotografias. Não sou somente o fotógrafo, mas o fotógrafo que realiza suas fotos perto da janela. Em seu livro Land Matters, a pesquisadora Liz Wells (2011), cita o exemplo de uma imagem de Lynn Silverman, intitulada Horizon no. 09. Esta imagem, também em preto e branco, produz uma reflexão sobre a posição do fotógrafo em relação à paisagem. Trata-se da fotografia de um deserto onde se vê na parte inferior da imagem as botas do fotógrafo e algumas pegadas. A relação da paisagem com o 
posicionamento do fotógrafo revela outros vestígios para além da paisagem capturada.

No caso da Figura 2, é um clique que projeta o olhar para fora ao mesmo tempo em que me situa atrás de uma segunda película de vidro, que é a janela do ônibus, uma operação que evidencia meu posicionamento ao mesmo tempo em que desvenda a paisagem pelo olhar da câmera. Neste momento o vidro reflete a paisagem, revela a chuva e aponta meu posicionamento dentro do ônibus e em relação à estrada. Em qualquer outro momento, a depender da luz, o vidro poderia apagar esta imagem e apenas me refletir por completo como espelho. Esta fotografia me obriga a reconhecer não somente a paisagem revelada pela fotografia, mas também a presença do fotógrafo.

Philippe Dubois (1998) considera a fotografia como o primeiro dispositivo do campo artístico que reivindica o lugar do "sujeito" que produz a obra no "processo de sua criação", neste caso específico, o lugar de quem fotografa no espaço. Percebe o "sujeito em processo" no ato de fotografar e não a fotografia como meio mecânico e impessoal. ${ }^{3}$ Ao refletir sobre o trabalho de Michael Snow ${ }^{4}$, em sua série de fotografias polaroide, com foco no modo como as fotografias foram feitas e em sua recepção, o autor afirma:

As cinco fotos polaroide restituem-nos a história da obra ao mesmo tempo em que a fazem. São ao mesmo tempo o próprio ato e sua memória. Por isso, pela simples observação das fotografias, o espectador pode desmontar a fabricação da obra (a recepção é aqui a inversão exata da produção: reversibilidade dos processos) (DUBOIS, 1998, p. 16, ênfase do original).

Na Figura 2 há uma consciência do espaço que não foi planejada, na qual me adiantei e me posicionei da melhor forma possível para tentar capturar a profundidade da estrada através da chuva na janela. Selecionei uma parte da placa no canto direito da foto e a estrada sumindo dentro do sertão que recebia as primeiras chuvas. Uma relação que também se afina com uma questão de gosto pessoal quando opto pelo preto e branco para fazer esta fotografia, pois aqui estou decidindo que aspecto deveria ter esta imagem e o que a própria paisagem já estava criando dentro de mim.

Neste sentido, apesar de todas as características que aproximam a fotografia do real, ela é antes de tudo uma interpretação possível que tenho desta paisagem. Não somente minha posição é denunciada, mas também as minhas escolhas. Acredito que o fato de ter vivido praticamente a vida toda no Ceará e ter visto de perto a seca, faz com que paisagens mais frias e com chuva chamem minha atenção, principalmente no Ceará. Os viajantes ficavam igualmente felizes com a chuva que chegava e os benefícios que ela traria.

${ }^{3}$ Segundo Dubois: "Toda foto implica que haja, bem distintos um do outro, o aqui do signo e o ali do referente. É até possível considerar que tudo o que faz a eficácia da fotografia está no movimento que vai desse aqui até aquele ali. São essas passagens, esses deslocamentos, essas idas e vindas que constituem literalmente o jogo, de mil maneiras diferentes." (DUBOIS, 1998, p. 88)

${ }^{4}$ A obra em questão se chama Authorization e foi realizada em 1969. (DUBOIS, 1998) 


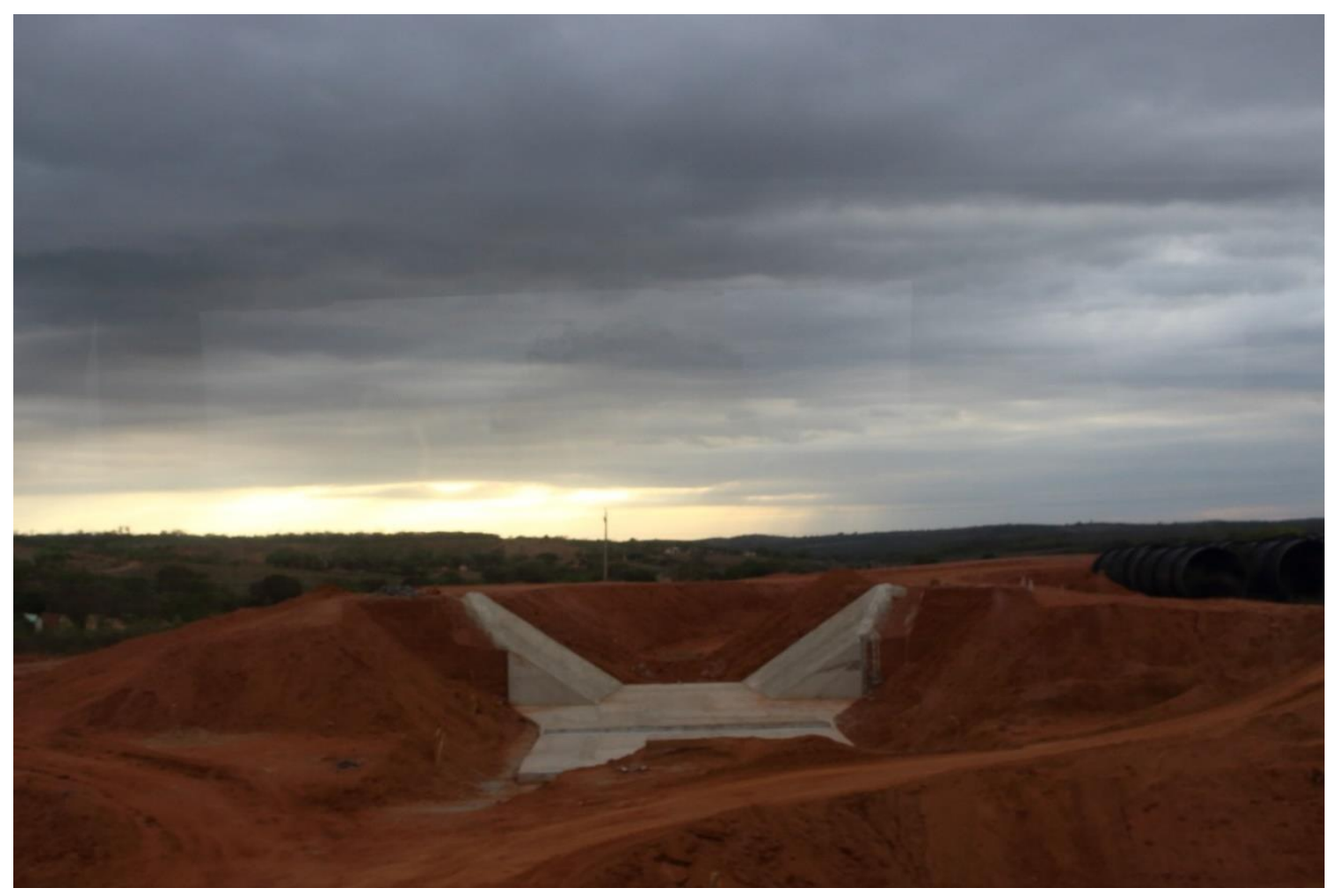

Figura 3. Fotografia do autor. Arquivo pessoal, 2017.

A Figura 3 mostra um dos afluentes da obra de expansão do rio São Francisco, que é de grande importância para o projeto de escrita da dramaturgia Odisseia 116. A ideia de rio que chega é uma temática na dramaturgia e para além disto atravessa os corpos das personagens, estabelecendo certos desequilíbrios e inconclusões, como pode ser percebido na cena cinco (saudade/transposição do Rio):

Casa, bagagens, cansaço de três dias. Uma das minhas irmãs com a qual eu não estava falando por conta de um conflito familiar era a única pessoa em casa. O portão estava aberto. O portão, a casa vazia e o seu grande olho redondo tentando disfarçar certo rancor. Eu entrei, pus a minha bagagem e quando olhei novamente o portão, a chave da casa estava lá junto ao cadeado aberto. O rio não passava mais naquela cidade. Tirei os sapatos e deixei os meus pés respirarem. Lembro de ter montado a câmera para falar algo. Montei o tripé, pus a câmera, coloquei uma cadeira num dos fundos de parede laranja e me posicionei diante da mesma... Um rio passava entre mim e a câmera e embaçava a imagem. Eu estava à deriva dentro de casa. Eu saí do Rio de Janeiro sem me despedir de ninguém, eu peguei três dias de ônibus e não consegui voltar. Eu não consegui falar. Diante da câmera, o rio afogou as minhas palavras. (LOPES, 2017, p. 7).

Este trecho da dramaturgia surgiu a partir da Figura 3, tendo em vista a ausência do rio como metáfora possível de elaboração dramatúrgica. Neste sentido a fotografia motiva a escrita dramatúrgica entre minhas questões autobiográficas, o ambiente árido e um rio que quase nunca chega, mas quando chega, afoga tudo o que está pela frente. Neste trecho, o tema é apresentado de forma metafórica.

Quando me mudei para o Rio de Janeiro no ano de 2014, a obra de transposição do rio São Francisco estava em pleno andamento, com máquinas e 
escavadeiras enormes transformando a paisagem. Já em janeiro de 2017, quando realizei a viagem do projeto, a obra encontrava-se completamente parada. Esta fotografia foi tirada em Salgueiro, interior do Estado do Ceará e cidade próxima a Iguatu.

A obra - e sua interrupção - constituíu uma situação bem complexa, com implicações sociais diretas e indiretas. As questões vão desde problemas respiratórios causados pela obra às populações das proximidades, até o próprio êxodo, pois se não há água para a agricultura familiar, também não há trabalho e subsistência para estas famílias. De acordo com Pedro Henrique Barreto (2009):

A história das secas na região Nordeste é uma prova de fogo para quem lê ou escuta os relatos que vêm desde o século 16. As duras consequências da falta de água acentuaram um quadro que em diversos momentos chega a ser assustador: migração desenfreada, epidemias, fome, sede, miséria. (BARRETO, 2009, p. 1).

Esta situação reflete diretamente nas estatísticas sobre migração, tendo em vista que, como exposto acima, a seca sempre foi um dos principais motivadores dos processos migratórios no Nordeste. O rio São Francisco também passa por longos períodos de seca e este fator traz medo para a população ribeirinha. Por essa razão a disputa política entre os estados pela água torna-se acirrada, pois parte da população não quer sofrer o risco de perder o rio na justificativa de abastecer outras regiões.

Ao longo do século $\mathrm{XX}$, várias medidas foram pensadas para sanar os problemas que a seca causa na região Nordeste, mas infelizmente, como observa Barreto, nenhuma delas teve um poder realmente efetivo, revelando-se antes como "remédios paliativos, não soluções". (BARRETO, 2009, p. 2)

Todavia, ao se pensar na transposição do rio São Francisco e em seu contexto político em relação ao êxodo, deve-se levar em conta as ações realizadas nos últimos quinze anos, como as políticas assistenciais criadas pela plataforma de governo do Partido dos Trabalhadores - PT, e dos presidentes do Brasil Luiz Inácio Lula da Silva e Dilma Rousseff. Tais projetos auxiliaram visivelmente a diminuição da migração de nordestinos para a região Sudeste, ainda que as questões relativas à seca ainda persistam. De acordo com Lucas e Rigotti (2016):

O aumento da participação dos programas sociais de transferência de renda nos orçamentos familiares, pode ter também atuado no sentido de produzir impactos nas tendências à migração intra-regional e inter-regional e devem ser descritos empiricamente. Diversos autores como Lima e Braga (2013), Gama (2012), Oliveira et al. (2015) e Ojima et al. (2014) constataram que a concessão de programas de transferências de renda como o Programa Bolsa Família atuam no sentido de reduzir a propensão migratória de indivíduos e famílias. Percebe-se que, de uma maneira geral a tendência à emigração inter-regional de nordestinos tem seguido uma trajetória de queda. Em relação à população residente total nordestina, a proporção de emigrantes era de 2,95\% em 1991, caindo para 2,67\% em 2000 e finalmente para 2,08\% em 2010. (LUCAS; RIGOTTI, 2016, p. 4). 
A recente diminuição do fluxo migratório deveu-se às políticas sociais tais como o programa bolsa família, a popularização universitária, a criação de escolas Federais de ensino médio-técnico e um dos mais importantes, o projeto garantiasafra, que assegura os pequenos produtores em casos de perda parcial ou total de suas plantações por conta da seca. Tais políticas também incentivaram nos últimos anos um movimento de retorno dos nordestinos para a sua região, tendo em vista que com mais dinheiro, mais Universidades, mais escolas Federais e maior desenvolvimento comercial, a região voltou paulatinamente a ser também mais atrativa. De acordo com Soares (2011):

As metrópoles não são mais o principal destino do fluxo migratório entre as regiões brasileiras e essa mobilidade diminuiu na última década, aponta pesquisa divulgada pelo Instituto Brasileiro de Geografia e Estatística (IBGE). Entre as principais mudanças, estão a perda de capacidade de atração populacional da região Sudeste, que apresentou saldo negativo no período, e a diminuição no número de pessoas que deixam o Nordeste. Os dados mostram que o número de migrações entre regiões vem apresentando queda. De 1995 a 2000, 3,3 milhões de pessoas deixaram a região em que viviam. O número caiu para 2,8 milhões, entre 1999 e 2004, e chegou a 2 milhões no intervalo de 2004 a 2009. A região Sudeste, entre 2004 e 2009, teve mais gente partindo do que chegando (saldo de negativo de $12,4 \mathrm{mil}$ ) e o Nordeste de onde saía boa parte de pessoas em busca de melhores condições de vida em outros estados do país, a perda de população ocorreu em escala mais de três vezes menor. (SOARES, 2011, p. 1).

Isto acontece porque a agricultura, apesar de ainda ser a principal fonte de renda das famílias pobres, não é mais a única. Todavia, estes programas assistenciais - que foram abandonados e/ou extintos pelo governo Temer e governo Bolsonaro - e oportunidades de emprego e estudos não conseguem contemplar todos os casos e famílias.

É o caso de um dos entrevistados para a escrita da dramaturgia Odisseia 116, pois em viagem apontou a seca como motivo para deixar Iguatu e morar no Rio de Janeiro, partindo sozinho e deixando para trás a esposa e seis filhos. Pensando neste rio que não chega nunca, elaborei uma cena inspirada neste depoimento, onde a imagem da Sereia se apresenta no rio São Francisco (LOPES, 2017). Na dramaturgia Odisseia 116, um rio também corre dentro dos entrevistados e por vezes é apresentada de maneira concreta e estrutural, como no trecho:

Não, não quero falar nada não, só tô um pouco cansado. Tem cachaça ainda? Me vê duas doses. Eu tô vindo de Iguatu. Iguatu não chove, é seco, cidade quente da peste. Já tô viajando há um dia já, indo pro Rio de Janeiro pra tentar trabalhar de servente porque a minha cidade não presta. Em Iguatu eu trabalhava de agricultor. Mas não chove. Disseram que ia passar um rio por lá. Passou? (LOPES, 2017, p.6).

A obra do rio que não termina, faz migrar, bem como a falta de chuva também o faz. A cartografia do rio que corre dentro do corpo por vezes é manifesta em palavra. O mesmo rio que corre, também seca este corpo por dentro. Estes foram os recursos encontrados por mim para tornar o rio vivo, para que água escorresse 
mesmo debaixo do sol quente. Minha forma de vivenciar a ânsia, espera, e saudade não somente da pessoa que vai chegar, mas da água, mudando assim toda a vegetação e vida no sertão. Como observa Wells:

A paisagem resulta da ação humana, da intervenção direta para fazer mudanças na terra (cidade, arquitetura paisagística, jardinagem...), ou de explorar como a terra pode ser representada (por escrito, arte, filme, fotografia, ou jornalismo diário e conversa casual). A 'paisagem' impõe uma certa ordem. (WELLS, 2011, p. 2). ${ }^{5}$

A Figura 3 é ao mesmo tempo um recorte do instante que revela a obra parada e a projeção efetiva de uma mudança na paisagem e de seu entorno no futuro, que muito infelizmente esbarra em questões políticas da má utilização de recursos tão corriqueiras no Brasil. Projetos urbanos que ficam no meio do caminho fazem, cada vez mais e com maior intensidade, parte das nossas paisagens, repercutindo diretamente nos processos de mudança e permanência das comunidades menos favorecidas.

O rio que não chega reverbera na dramaturgia Odisseia 116 e por ser uma questão estrutural, aproxima-se e demonstra aspectos da relação que os migrantes têm com a viagem e com o ato de voltar. De acordo com o estudo do Instituto de Pesquisa Econômica Aplicada - IPEA (2010):

Muitos migrantes voltam. Outros mantêm comunicações por palavras com parentes, amigos e familiares. Há ainda os que estendem essas comunicações ou as reduzem ao envio de recursos econômicos, silêncio motivado pelo sofrimento das saudades, pela vergonha, pelo orgulho duro das atividades e das situações de vida experimentadas, pela expectativa de reencontro. Em todo caso, o migrante nem sempre é um sem lugar, inclassificável. Ele ocupa posições no mundo do trabalho; é objeto de especulações como "nordestino, nortista, paraíba", "é feito para trabalhar na construção civil como pedreiro ou ajudante de pedreiro"; ou simplesmente suscita, como nos designativos citados, reações de rejeição e preconceito. (BARBOSA, ARAúJO, ARAúJO, 2010, p. 3)

Algumas destas características são perceptíveis na dramaturgia Odisseia 116. O medo do novo e a vontade de ficar muitas vezes são traduzidos em frases do tipo: "não tem o que fazer ou, se não tem outro jeito a gente muda". Na Odisseia homérica, o desejo de retornar de Odisseu é justamente o contraponto ao fato de também não ter desejado viajar em guerra, tendo buscado alternativas para fugir desta responsabilidade, muito embora sem sucesso (WERNER, 2014). Na Odisseia 116, a vontade e o desejo de ficar mostram-se como uma constante na vida dos migrantes que atravessaram o projeto e cederam seus depoimentos.

É importante ressaltar que a dramaturgia Odisseia 116 apresenta também uma outra característica, movida pelo sentimento de me sentir estrangeiro ${ }^{6}$ no meu próprio local por motivos diversos e de buscar alternativas ou formas de visualizar a

\footnotetext{
5 Tradução minha.

${ }^{6}$ Nestor Canclini (2009) defende algumas formas de ser estrangeiro, para além de migrar de um país para outro e o não reconhecimento do seu espaço no ato de retornar é uma delas.
} 
situação através de outras perspectivas. As formas que encontrei neste projeto foram a fotografia e a dramaturgia. Para Canclini: "nós também nos sentimos estrangeiros em um mundo movido por conflitos bélicos, ecológicos e financeiros, onde parecem prevalecer as lógicas de destruição." (CANCLINI, 2009, p. 2)7. A paisagem que deveria ter se transformado entre a primeira viagem em 2014 e a segunda, em 2017, mas que encontra-se estacionada em razão da obra parada, talvez seja o momento no qual, dentro da dramaturgia Odisseia 116, eu me veja como estrangeiro, pois mesmo antes de chegar em casa, não consigo suprir as expectativas das melhoras que esperava encontrar. Foi neste momento que me senti estrangeiro dentro da paisagem.

Dentro desta perspectiva, me sentir estrangeiro está relacionado primeiramente ao meu estranhamento dentro das próprias paisagens, pois não via acontecerem algumas transformações que julgava imprecindíveis, como a transposição do rio São Francisco. Com os valores gastos e a obra não acabada, me sentir estrangeiro significa também me sentir enganado, perdido, desconhecendo o próprio espaço e à deriva.

A desigualdade, a pobreza e a seca fazem com que eu me sinta estrangeiro. Bem como, por outro lado, que sinta empatia para com aqueles que vivem ao lado da obra e à sua espera, sofrendo com suas consequências, mas que ainda não puderam usufruir dos seus benefícios.

O rio e por onde ele passa é uma questão da dramaturgia Odisseia 116 que vai de encontro a este pensamento, quando constatamos mais uma vez que a qualidade de vida da população é suprimida pelo descaso político, como é caso da interrupção do projeto de transposição do rio São Francisco para estados como o Ceará que necessitam desta água.

A ausência da água na dramaturgia Odisseia 116, vem de forma política e concreta, como no último fragmento da dramaturgia apresentada, onde um entrevistado assume que muda-se porque, com a ausência da água, não tem como trabalhar. E aparece também de forma metafórica, simbolizando morte, saudade e incapacidade de manter diálogo, como no trecho a seguir da Cena 06: revisitando fotografias:

\footnotetext{
Cheguei, mas quando eu cheguei não mais me reconheciam, e sempre quando me olhavam parecia que estavam buscando o que havia de diferente em mim. Cheguei e me sentia um campo de arqueologia, cheio de ossos antigos. Cheguei, chorei, eu sei que eu saí mas eu cheguei, eu voltei... Porra. Cheguei, como se chegar fosse buscar a nascente de um rio seco. Rachadura, buraco, asfalto, praça, farmácia, farmácia, teatro fechado, farmácia, igrejas são várias. (LOPES, 2017, p. 4)
}

Sentir-se estrangeiro neste sentido motiva um lugar de discurso elaborado pelo texto e pela fotografia no projeto Odisseia 116. Para Canclini, ser estrangeiro ou migrante é um campo propício para pensar em como nos comunicamos e representamos, tendo em vista que se está num lugar radical de experimentação da paisagem. Tal radicalidade acontece porque o estrangeiro em sua dinâmica experimenta a incerteza da paisagem, renomeando-a em constante experimentação.

\footnotetext{
7 Tradução minha.
} 
(CANCLINI, 2009).

Para mim, ser estrangeiro se expande a partir da escrita da dramaturgia Odisseia 116, pois ao mesmo tempo em que experimento a paisagem como estrangeiro, consigo por vezes ter consciência destas mesmas paisagens no meu processo de retorno e o que me causam justamente por serem paisagens reconhecíveis, mas que em certas camadas não mais reconheço como minhas. Então estabeleço na escrita dramatúrgica, a frustração por esta distância, ao mesmo tempo em que ensaio tentativas de reaproximação.

Também nas paisagens urbanas a intervenção humana e suas implicações podem ser percebidas com facilidade. Em seu artigo El paisaje urbano (2010), Javier Maderuelo diz: "a paisagem urbana não é a cidade nem nenhum de seus enclaves, senão a imagem que dela se tira, seja ela individual ou coletiva. (MADERUELO, 2010, p. 575$)^{8}$

A paisagem urbana é construída no Brasil em parte por meio de grandes articulações políticas, onde prevalece a ausência de bom-senso, já que os políticos aproveitam-se do não acompanhamento destes projetos por parte da sociedade civil e do poder público. Em geral, a maior parte dos projetos é interrompida logo após as eleições, quando as legendas partidárias mudam na gestão do poder, por conta muitas vezes de irresponsabilidade fiscal.

Os pesquisadores José Roberto R. Afonso e Marcos Nóbrega, no artigo intitulado Responsabilidade fiscal: uma obra inacabada (2009), defendem que há no Brasil um grande avanço com a Lei de Responsabilidade Fiscal (LC no 101/00). No entanto, relevantes regras presentes na lei ainda hoje não foram implementadas, não entrando em vigor. As normas presentes na lei têm efeito apenas legal, não prático. (AFONSO, NOBREGA, 2009)

Estas características afetam os cidadãos diretamente, que ficam com a ausência de uma estrutura básica de moradia, saúde, educação, saneamento básico e cultura, por exemplo. Obras são terminadas com atrasos e mesmo assim, muitas delas continuam funcionando sem a sua plenitude, como é o caso de vários hospitais ou da transposição do Rio São Francisco. Esta espera incessante pela finalização de projetos e acesso, faz o ato de migrar e tornar-se estrangeiro mais interessante para algumas pessoas.

A indignação e falta de meios básicos de sobrevivência atravessa a dramaturgia Odisseia 116 de maneira bastante forte, tendo em vista que isto era presente em todos os relatos nas viagens. Eu migrei para estudar e crescer profissionalmente. Mesmo morando em favelas da cidade do Rio de Janeiro, reconheço meu lugar de privilégio amparado pelo ensino superior. A maior parte dos viajantes não teve a mesma sorte que eu e isto pode ser percebido no início da dramaturgia, na cena 01: início da viagem.

O Ricardo estava voltando porque a sua cidade deveria estar melhor depois que um ano se passou, as notícias que ele recebia via whatsapp eram que em Monsenhor Tabosa, cidade do interior do Ceará, já tinha chegado asfalto e ele estava indo reencontrar a sua esposa... Eraldo, pernambucano de Exu, terra de Luiz Gonzaga, voltou depois de 17 anos morando no Rio de Janeiro. Chegou na rodoviária com duas malas, uma em cada lado da mão buscando

8 Tradução minha. 
pela sua família, só que seus irmãos não reconheciam mais o seu rosto. (LOPES, 2017, p.2)

Os viajantes em sua maioria tinham concluído apenas o ensino fundamental e muitos deles não tinham o conhecimento básico para conseguirem comprar uma passagem de avião via internet, por exemplo ${ }^{9}$. Muitos trabalhavam em empregos informais e continuavam tendo dificuldades no Rio de Janeiro, onde as oportunidades não se apresentavam como os mesmos esperavam.

\section{Considerações Finais}

Os períodos extensos de seca dificultam e por muito impossibilitam a agricultura familiar e os programas assistenciais não são suficientes para a subsistência das famílias. No Ceará, cito como exemplos a seca de 1915, tratada pela escritora cearense Rachel de Queiroz no romance $O$ quinze, bem como os campos de concentração no Ceará nos anos de 1915 e 1932, antes mesmo dos campos de concentração de Auschwitz, Alemanha. Fatos históricos como estes deveriam servir de precedentes para o fomento de políticas públicas e não apagados. A dramaturgia Odisseia 116 traz uma questão contemporânea como a transposição do Rio São Francisco, tentando não perder de vista o passado.

O Ricardo, viajante e morador de Monsenhor Tabosa, diz em sua entrevista: "eu tenho certeza de que se os nordestinos ganhassem um terço do salário e tivessem um terço das oportunidades que as pessoas da cidade grande têm, elas com certeza não iriam embora." (SANTOS, 2016). Geralmente, as pessoas mudamse da sua terra por algum motivo estrutural. As questões que atravessam o indivíduo que deseja migrar não são banais. No caso desta emigração em específico, o clima e as oportunidades são decisivos.

Na dramaturgia Odisseia 116, a motivação para realizar a viagem é apresentada de forma estrutural, bem como afetiva, trazendo temas como saudade, distância, solidão, perdão, relações inacabadas, desejo de vingança e rancor. Estas temáticas estão presentes fortemente na Odisseia homérica, aparecendo a partir dos personagens e da narrativa do próprio Ulysses, bem como o meu desejo de retorno em maior ou menor medida. A partir da viagem, percebi inúmeros pontos de interseção entre a Odisseia homérica, as motivações dos viajantes entrevistados e as próprias questões pessoais que eu enquanto dramaturgo e artista precisavam tomar consciência e que me inspiraram neste processo de escrita.

A paisagem que muda radicalmente relaciona-se com as características emigratórias do nordestino. A dramaturgia Odisseia 116 percebe a seca que faz ir embora e a chuva que faz com que nordestinos voltem para sua terra. Esta temática foi cantada por Luiz Gonzaga, escrita por Patativa do Assaré e tantos outros artistas da região que usaram a relação entre clima e emigração como disparadora. Acredito que a forma fragmentada da escrita Odisseia 116, bem como a tríade que a organiza: questões autobiográficas, Odisseia homérica como obra de inspiração e relatos e fotografias em viagem, me auxiliam numa pesquisa de cunho autoral na forma e no conteúdo.

\footnotetext{
${ }^{9}$ Cito este exemplo, pois uma passagem de avião entre o Rio de Janeiro e o Ceará custa em média o mesmo preço de uma passagem de ônibus. No entanto, a viagem de ônibus dura quarenta e oito horas e a de avião dura três horas.
} 
Apontei como fotografias (assim como paisagens), nos inspiram, são utilizadas e são indispensáveis para a construção da dramaturgia Odisseia 116, sendo citadas no texto e tomadas como pontos de referência para as pessoas entrevistadas. 0 caráter de testemunho e posterioridade também se evidencia na dramaturgia, e paisagens que deveriam ter se movimentado, mas que permaneceram inertes, são evidenciadas, como no caso da obra de transposição do rio São Francisco.

Para além disto, as paisagens que são construídas a partir das minhas referências e das referências das pessoas em viagem são materiais utilizados para a construção do texto. Tais materiais não são a comprovação do real, mas uma interpretação do possível sobre a paisagem. A fotografia não somente aponta para as paisagens, mas também para o meu lugar de artista-pesquisador ensaiando as primeiras fotos numa viagem de retorno para casa.

\section{Referências}

AFONSO, José Roberto R; NÓBREGA, Marcos. Responsabilidade Fiscal: uma obra inacabada. Revista Controle: Doutrinas e artigos. Vol. 7, No. 1, 2009, págs. 1530

BARILLO, M. Fotografia ficção: sobre a fotografia de performances e performatividades. Conceição/Conception, Campinas, SP, v. 8, n. 2, p. 276-297, 2019. DOI: 10.20396/conce.v8i2.8656452. Disponível em: https://periodicos.sbu.unicamp.br

/ojs/index.php/conce/article/view/8656452. Acesso em: 15 maio. 2021.

BARBOSA, F.; ARAÚJO, H. E.; ARAÚJO, M. Migração interna no Brasil. Comunicado IPEA. n. 61, 17 de agosto de 2010. Disponível em: http://www.ipea.gov.br

/portal/images/stories/PDFs/comunicado/100817_comunicadoipea61.pdf>. Acesso em: 20 jan. 2018 .

BARRETO, Pedro Henrique. História - Seca: fenômeno secular na vida dos nordestinos. Revista Desafios do Desenvolvimento SBS. 2009.

BENJAMIN, Walter. Magia e técnica, arte e política: ensaios sobre literatura e história da cultura. Tradução Sérgio Paulo Rouanet. $8^{a}$ edição. Revista. São Paulo: Brasiliense, 2012.

CANCLINI, Néstor García. Introducción: los muchos modos de ser extranjeros. In: Extranjeros en la tecnología y en la cultura. Coleção Fundação Telefônica. 2009.

DUBOIS, Philippe. O ato fotográfico e outros ensaios. Trad. Marina Appenzeller. Campinas - SP, 1998, coleção ofícios de arte e forma.

GRÉSILLON, Almuth; MERVANT-ROUX, Marie-Maᄀdeleine; BUDOR, Dominique. Por uma Genética Teatral: premissas e desafios. Revista Brasileira de Estudos da 
Presença, Porto Alegre. v.3, n.2, maio/ ago, pp. 379-403. 2013.

LOPES, Cleilson Queiroz. Odisseia 116. Dramaturgia. 2017. Manuscrito inédito

LOPES, Cleilson Queiroz. O Trauma e a Cicatriz na escrita da Odisseia 116. Revista

Cena. Porto Alegre. n. 33, 2021

LUCAS, Leonardo Azevedo Pampanelli; RIGOTTI, José Irineu Rangel. Análise das migrações inter-regionais e intrarregionais nordestinas: novos paradigmas. Anais do XX Encontro Nacional de Estudos Populacionais. 2016.

MADERUELO, Javier. El paisaje urbano. Estudios Geográficos Vol. LXXI, 269, pp. 575-600, julho-dezembro 2010.

SANTOS, Ricardo. Ricardo cantor. Entrevista inédita concedida a Cleilson Queiroz Lopes para o projeto Odisseia 116. Fevereiro de 2016.

SOARES, Nicolau. IBGE mostra queda na migração entre regiões do Brasil. Rede Brasil Atual. Publicado em: 15/07/2011 e disponível em: https://

www.redebrasilatual.com.br/cidades/2011/07/migracoes-entre-regioes-caem-nobrasil-diz-ibge

SONTAG, Susan. Sobre Fotografia. São Paulo: Companhia das Letras, 2004.

WELLS, Lis. Land Matters: Landscape Photography, Culture and Identity. London: I.B.Tauris \& Co. Ltd 2011.

WERNER, Cristian (tradução, introdução e posfácio). Odisseia: Homero. $1^{a}$ ed, São Paulo. Cosac Naify, 2014. 